Defeat on education bill

\section{London}

BRITISH academics, flushed by several victories in the long battle with the government over the education reform bill, suffered a defeat last week. A House of Lords' amendment on university funding was reversed in the House of Commons. As the bill now stands, grants made to universities will be subject to "terms and conditions" laid down by the new Universities Funding Council (UFC).

In the bill's original form, the word 'payments', not 'grants', was used. The wording was changed in the House of Lords to "grants, specifying particular obligations and subject to general guidance" (see Nature 334, 7; 1988). Academics saw this change as necessary if universities were to retain some independence.

The government has now agreed to retain the word 'grants', but has reinserted the 'terms and conditions' clause. The Secretary of State for Education and Science, Mr Kenneth Baker, says this is essential to allow the ear-marking of funds for specific purposes, such as the current restructuring of university departments and in order to ensure proper accountability. But the government denies that the UFC will have more wide-ranging power than the University Grants Committee (UGC) now has.

At present, UGC advises the government on the annual grant to each university. UGC can offer 'advice' on how money is spent, but that can be ignored on the understanding that future grants could be cut. Yet this bill empowers UFC to demand repayments of grants with interest if the conditions of the payment are not met.

In view of other concessions by the government, the Committee of ViceChancellors and Principals (CVCP), has agreed to accept the clause as it now stands, but the Lords may yet oppose the clause this week, thus delaying the bill. But a defeat in the House of Lords seems unlikely. CVCP remains concerned about the interpretation of the clause and the proportion of university finances to be ear-marked. These issues will be discussed with the government.

The concessions by the government on higher education include the acceptance of a statutory guarantee of academic freedom in the face of the abolition of tenure; academics will have "freedom within the law to question and test received wisdom and to put forward new ideas and controversial and unpopular opinions without placing themselves in jeopardy of losing their jobs or privileges".

Christine McGourty

\title{
OTA produces a consumer's guide to new rockets
}

\section{Washington}

IT is a rather specialized market, but the Congressional Office of Technology Assessment (OTA) has produced a buyer's guide for those considering the purchase of new launch systems to maintain and enhance the US presence in space.

The OTA report argues that before deciding on a launch system, Congress must decide where the US space programme is headed. With no expansion of space activities, the current launch fleet of the space shuttle and expendable launch vehicles (ELVs) - including the Titan II, III and IV, Scout, Delta and Atlas/ Centaur rockets - can reasonably be expected to place up to 956,000 pounds of payload into low Earth orbit. But for an expanded space effort, including deployment of a space-based ballistic missile defence, full deployment of the space station and human exploration of Mars, the current capabilities are insufficient.

One option is to enhance the existing launch fleet. The National Aeronautics and Space Administration (NASA) is funding work on an advanced solid rocket motor that would replace the solid rocket boosters currently used on the space shuttle. Liquid rocket boosters are also being developed that would be more powerful than the solid fuel rocket now used. Both systems would add approximately 12,000 pounds the shuttle's lift capabilities.

By making the shuttle's external fuel tank out of an aluminium-lithium alloy, another 12,000 pounds could be added to the maximum cargo load. OTA estimates that these improvements, coupled with enhanced performance from existing ELVs and slightly higher launch rates, could raise annual launch capacity for lowEarth orbit to $1,600,000$ pounds. OTA considers this option a 'best buy' if the US space programme is to stay at current or slightly enhanced levels of activity.

But other options are definitely on the drawing board. NASA, along with some allies in Congress, sees development of Shuttle-C as a smart way to go. Shuttle-C is an unpiloted version of the current shuttle. It would use the same solid rocket boosters and external fuel tanks, but in place of the orbiter there would be a payload shroud with either two or three main engines. Shuttle-C would be capable of lifting a 100,000 -pound payload into lowEarth orbit. OTA points out that there have been objections to this proposal because it "places all our eggs in one basket", relying on the same technology for piloted and unpiloted flight. OTA says Shuttle-C's strongest selling point is that it would considerably shorten the time needed to deploy the space station. But it is still not clear that Congress will find the funds to permit the space station to go forward.

Another near-term option is a transition launch system based on current technology, but capable of lifting up to 150,000 pounds into orbit. Congress ordered the Air Force not to pursue this option, in large part because it wanted to forestall its use for an early deployment of a spacebased missile defence foreseen by the Strategic Defense Initiative. But OTA says the idea should not be abandoned if Congress wants an increased launch capability by the mid- to late-1990s.

Along with NASA, the Air Force is currently pursuing a project known as the Advanced Launch System (ALS), designed to bring launch costs down to $\$ 300$ per pound for low Earth orbit. Richard DalBello, project director for the OTA report, says ALS got off to a slow start because NASA and the Air Force wrangled over how the project should be managed. Now the Air Force seems to be calling the shots, and expects to have a preliminary design review completed by June 1990.

The National Aerospace Plane proposed by the Reagan administration represents a dramatic departure from current launch technologies, requiring 'scramjet' engines that could operate in the atmosphere and space. The OTA report says there are several major technical hurdles to overcome in this project, but the payoff could be a fleet of vehicles capable of taking off from conventional runways and flying directly to Earth orbit.

Although ALS and the aerospace plane are intended to use new technology, there are even more unconventional options being considered for getting payloads off the Earth. A ram cannon uses a barrel filled with fuel that ignites as a projectile passes through it. According to OTA, tests of the ram cannon have propelled a 0.1 pound projectile at $20,000 \mathrm{~g}$ to a velocity of 1.25 miles per second, 20 per cent of that needed to reach Earth orbit.

More exotic still is a proposed rocket using anti-hydrogen fuel. Only 35 milligrams of anti-hydrogen would be needed to boost 30 tons into low Earth orbit. One drawback to this scheme is that at current rates of production it would take 19 million years to produce the necessary amount of anti-hydrogen. But with a 10 gigawatt solar-powered orbital production facility, some estimates place production time at only five weeks. OTA is not necessarily endorsing this option at present.
Joseph Palca 